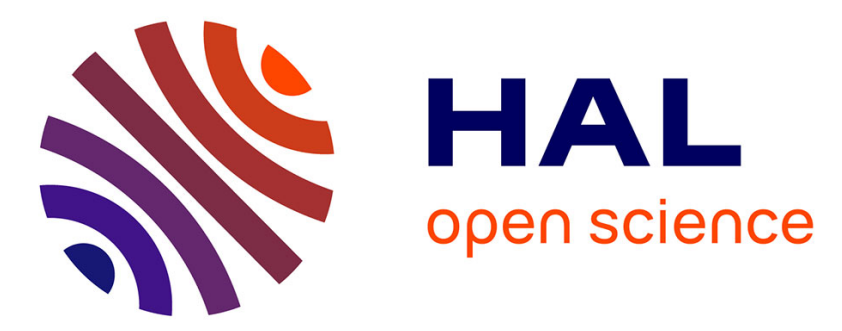

\title{
Surgery for cyst dilatation of a ventriculus terminalis in adults: Keep it simple!
}

\author{
Constantin Tuleasca, Yohan Ducos, Steven Knafo, Marc Levivier, Nozar \\ Aghakhani, Fabrice Parker
}

\section{- To cite this version:}

Constantin Tuleasca, Yohan Ducos, Steven Knafo, Marc Levivier, Nozar Aghakhani, et al.. Surgery for cyst dilatation of a ventriculus terminalis in adults: Keep it simple!. Neurochirurgie, inPress, 10.1016/j.neuchi.2020.04.003 . hal-02879701

\section{HAL Id: hal-02879701 https: / hal.sorbonne-universite.fr/hal-02879701}

Submitted on 24 Jun 2020

HAL is a multi-disciplinary open access archive for the deposit and dissemination of scientific research documents, whether they are published or not. The documents may come from teaching and research institutions in France or abroad, or from public or private research centers.
L'archive ouverte pluridisciplinaire HAL, est destinée au dépôt et à la diffusion de documents scientifiques de niveau recherche, publiés ou non, émanant des établissements d'enseignement et de recherche français ou étrangers, des laboratoires publics ou privés. 


\section{Journal Pre-proof}

Surgery for cyst dilatation of a ventriculus terminalis in adults: keep it simple!

Constantin Tuleasca MD PhD Yohan Ducos MD Steven Knafo MD PhD Marc Levivier MD PhD IFAANS Nozar Aghakhani MD PhD

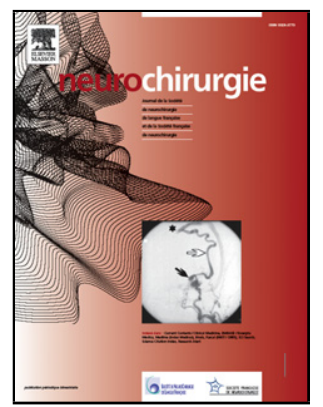

Fabrice Parker MD PhD

PII:

S0028-3770(20)30087-4

DOI:

https://doi.org/doi:10.1016/j.neuchi.2020.04.003

Reference:

NEUCHI 1087

To appear in:

Neurochirurgie

Received Date:

15 March 2020

Please cite this article as: Tuleasca C, Ducos Y, Knafo S, Levivier M, Aghakhani N, Parker F, Surgery for cyst dilatation of a ventriculus terminalis in adults: keep it simple!, Neurochirurgie (2020), doi: https://doi.org/10.1016/j.neuchi.2020.04.003

This is a PDF file of an article that has undergone enhancements after acceptance, such as the addition of a cover page and metadata, and formatting for readability, but it is not yet the definitive version of record. This version will undergo additional copyediting, typesetting and review before it is published in its final form, but we are providing this version to give early visibility of the article. Please note that, during the production process, errors may be discovered which could affect the content, and all legal disclaimers that apply to the journal pertain.

(C) 2020 Published by Elsevier. 


\title{
Surgery for cyst dilatation of a ventriculus terminalis in adults: \\ keep it simple!
}

\section{Chirurgie pour dilatation kystique du ventricule terminal: \\ l'art de la simplicité}

\author{
Constantin Tuleasca ${ }^{1,2,3,4,5}$, MD-PhD, Yohan Ducos ${ }^{1}$, MD, Steven Knafo, MD-PhD ${ }^{1}$, Marc Levivier ${ }^{3,4}$, \\ MD, PhD, IFAANS, Nozar Aghakhani ${ }^{1}, \mathrm{MD}, \mathrm{PhD}$ AND Fabrice Parker $^{1}, \mathrm{MD}, \mathrm{PhD}$ \\ ${ }^{1}$ Assisstance Publique-Hôpitaux de Paris, Hôpitaux Universitaires Paris Sud, Centre Hospitalier Universitaire de \\ Bicêtre, Service de Neurochirurgie, Le Kremlin-Bicêtre, France; \\ ${ }^{2}$ Sorbonné Université, Faculté de Médecine, Paris, France; \\ ${ }^{3}$ Neurosurgery Service and Gamma Knife Center, Lausanne University Hospital (CHUV), Lausanne, Switzerland \\ ${ }^{4}$ Université de Lausanne (Unil), Faculté de Biologie et de Médecine (FBM); \\ ${ }^{5}$ Signal Processing Laboratory (LTS 5), Swiss Federal Institute of Technology (EPFL);
}

\section{Corresponding author:}

Constantin Tuleasca, MD-PhD, Assisstance Publique-Hôpitaux de Paris, Hôpitaux Universitaires Paris Sud, Centre Hospitalier Universitaire de Bicêtre, Service de Neurochirurgie, Le Kremlin-Bicêtre, France- 78, Rue Général Leclerc, 94270, Le Kremlin-Bicêtre, France; Sorbonné Université, Faculté de Médecine, Paris, France; Université de Lausanne (Unil), Faculté de Biologie et de Médecine (FBM); Tel: +41-21-314-26-02; Fax: +41-21-314-11-99;

e-mail: constantin.tuleasca@gmail.com; constantin.tuleasca@chuv.ch

\section{Dear Editor,}

Ventriculus terminalis (VT) is defined as an ependymal cell lined cavity within the conus medullaris and containing cerebrospinal fluid (CSF)(1-3). This is considered as an anatomical variance up to the age of 5 and has been classically described on ultrasonography during the neonatal period(4). The etiology of such cystic dilatation is debatable. While some authors consider VT cysts as a developmental defect (appearing between the 4-th and 6-th intrauterine life), others report trauma, vascular or compression as the main cause $(3,5)$.

In normal adults, the VT can only be demonstrated on histology, as it is not routinely seen on imaging(6). The diagnosis is so usually incidental. They are frequently asymptomatic, especially in children. However, symptoms may appear due to the cystic dilatation itself with further compression of the nerve tissue in conus medullaris.

The management of rare cyst dilatation of VT, with less than 30 cases reported in the literature, is not well established(1). Conservative management, marsupialization, or placements of a " $\mathrm{T}$ " drain 
have been described. We describe our experience in 3 cases in this rare pathology(7). We share our surgical indications and describe our operative approach.

\section{Case series presentation}

\section{Case \#1:}

A 70 years-old female patient presented with progressive motor deficit during the past 3 years, mainly at the levels L5 left, L5 right and S1 right. MRI revealed cystic dilatation of the VT at the level of T12 (figure 1). The cavity was hypointense in T1 and hyperintense in T2, fulfilled with fluid with the same signal as the CSF. She underwent surgical exploration with laminectomy and marsupialization, which was uneventful. Postoperative clinical examination showed complete motor recovery.

\section{Case \#2:}

A 55 years-old female patient had been previously operated for a cystic dilatation of the VT at the levels T12 thirteen years back. During the following 10 years after surgery, she presented with clinical and radiological uneventful course. Afterwards, she presented with left lower leg weakness and progressive sciatica. MRI revealed progressive increase of the VT cyst's volume (figure 2). Laminectomy and further cyst marsupialization were performed. Postoperative clinical examination revealed full recovery of the motor symptoms. Postoperative MRI showed major decrease in size, which persisted up to 5 years after the second surgery, date of the last follow-up of the patient.

\section{Case \#3:}

A 57 years-old female patient presented with left leg pain during the past 3 years and, more recently, sacral pain. During the past months she also developed a medullary claudication. Clinical examination revealed a bilateral L5 motor root deficit. Preoperative MRI showed a cystic dilatation of the VT at the levels T11-T12-L1. She underwent surgical exploration with T12-L1 laminectomy, myelotomy, and dissection of local arachnoiditis and placement of a shunt fixed to pia matter. Postoperative clinical course was marked by complete motor recovery.

\section{Discussion}

Ventriculus terminalis cyst dilatations are rare and challenging cases. Asymptomatic patients with no radiological progression can benefit from regular clinical and radiological follow-up. Symptomatic cases with posterior cysts can be offered laminectomy, myelotomy and marsupialization. In patients presenting with additional focal arachnoiditis, which might be subject of further cyst recurrence, a " $T$ " shunt can be placed and further attached to pia matter.

Physiological role of VT is currently undiscovered. The most common theory places VT at the cross point between ending of Reissner fibers (which extend from subcomisural organs of the 
epithalamus to VT), while storing neurosecretory substances. Their potential pathophysiological functions are mainly of mechanoreception, to indicate variations in CSF pressure. Furthermore and by this, they can regulate the quality of CSF.

An isolated rare VT is not typically associated with dysraphic pathologies and is usually seen during fetal development, while being present in vast majority of cases after birth. Before the age of 5 is considered normal anatomical variance, with propensity to further regress $(4,8)$. In persistent asymptomatic cases, other abnormalities of craniospinal axis, such as spinal cord tethering, tumors etc should be excluded. In other associated particular conditions, such as syringomyelia, dilatation is usually present in upper parts of spinal cord and is frequently associated with Chiari type I, myelomeningocele etc(9). Central canal is normally broadest at conus medullaris level and if prominent or enlarged, any cystic neoplasm or syringohydromyelia should be formally excluded.

The exact origin of clinical and radiological decompenssation in adults of cyst enlargement of VT remains unclear. Some authors have hypothesized that inflammatory processes (such in our case \#3), medullary ischemia, medullary compression or trauma could interfere and create a lack of communication between the VT and the ependymal canal(2, 3, 5, 6). Pathophysiologically, this engenders an altered CSF flow within central canal or leads to disturbance of the Reissner Fiber (a subependymal secretory product), which has a role in CSF regulation(10).

MRI plays the role of standard paraclinical assessment. The former classically shows anatomical location at the level of the conus medullaris, T12-L2, with a cystic cavity presenting with same signal as the CSF, and no signs of solid portion. Furthermore, there is no evidence of tumor signs and no contrast enhancement. Further investigations might include electromyography examination, lemniscal conduction or urodynamic assessment, shall urinary symptoms be present.

Recurrence is unusual and can be further treated by new surgical exploration. In this context, placement of a " $\mathrm{T}$ " drain might be also discussed. $\mathbf{s}$

\section{Figures}

Figure 1: illustrative case 1 with preoperative MRI in sagittal, axial and coronal plane, while exemplifying different sequences.

Figure 2: illustrative case 2 with preoperative MRI in sagittal and axial plane, while demonstrating different MR sequences at 2 years (2.1.), 1 year (2.2.) and 6 months (2.3.) preoperatively and 18 months after second surgery (2.4.), respectively.

\section{Compliance with Ethical Standards: yes}


Funding: Funding: Constantin Tuleasca gratefully acknowledges receipt of a 'Young Researcher in Clinical Research Grant' (Jeune Chercheur en Recherche Clinique) from the University of Lausanne (UNIL), Faculty of Biology and Medicine (FBM) and the Lausanne University Hospital (CHUV)

Conflict of interest: All authors certify that they have no affiliations, with or involvement in any organization or entity with any financial interest (such as honoraria; educational grants; participation in speakers' bureaus; membership, employment, consultancies, stock ownership, or other equity interest; and expert testimony or patent-licensing arrangements), or non-financial interest (such as personal or professional relationships, affiliations, knowledge or beliefs) in the subject matter or materials discussed in this manuscript.

Ethics approval: Ethical Committee Approval has been required, according to the French rules, at the Assistance Publique, Hopitaux de Paris, Paris, France for this retrospective review of cases.

\section{References}

1. Ganau M, Talacchi A, Cecchi PC, Ghimenton C, Gerosa M, Faccioli F. Cystic dilation of the ventriculus terminalis. Journal of neurosurgery Spine. 2012 Jul;17(1):86-92. PubMed PMID: 22559279.

2. Celli P, D'Andrea G, Trillo G, Roperto R, Acqui M, Ferrante L. Cyst of the medullary conus: malformative persistence of terminal ventricle or compressive dilatation? Neurosurgical review. 2002 Mar;25(1-2):103-6. PubMed PMID: 11954762.

3. Kumar R, Nayak SR, Krishnani N, Chhabra DK. Spinal intramedullary ependymal cyst. Report of two cases and review of the literature. Pediatric neurosurgery. 2001 Jul;35(1):29-34. PubMed PMID: 11490188.

4. Unsinn KM, Mader R, Gassner I, Kreczy A, Freund MC. Sonography of the ventriculus terminalis in newborns. AJNR American journal of neuroradiology. 1996 May;17(5):1003-4. PubMed PMID: 8733982.

5. Dhillon RS, McKelvie PA, Wang YY, Han T, Murphy M. Cystic lesion of the ventriculus terminalis in an adult. Journal of clinical neuroscience : official journal of the Neurosurgical Society of Australasia. 2010 Dec;17(12):1601-3. PubMed PMID: 20817465.

6. Choi BH, Kim RC, Suzuki M, Choe W. The ventriculus terminalis and filum terminale of the human spinal cord. Human pathology. 1992 Aug;23(8):916-20. PubMed PMID: 1644436.

7. Borius PY, Cintas P, Lagarrigue J. [Ventriculus terminalis dilatation in adults: A case report and review of the literature]. Neuro-Chirurgie. 2010 0ct;56(5):386-90. PubMed PMID: 20097392. Dilatation du ventriculus terminalis chez l'adulte : a propos d'un cas et revue de la litterature.

8. Coleman LT, Zimmerman RA, Rorke LB. Ventriculus terminalis of the conus medullaris: MR findings in children. AJNR American journal of neuroradiology. 1995 Aug;16(7):1421-6. PubMed PMID: 7484626. 
9. Byrd SE, Harvey C, Darling CF. MR of terminal myelocystoceles. European journal of radiology. 1995 Sep;20(3):215-20. PubMed PMID: 8536754.

10. Ciappetta P, D'Urso P I, Luzzi S, Ingravallo G, Cimmino A, Resta L. Cystic dilation of the ventriculus terminalis in adults. Journal of neurosurgery Spine. 2008 Jan;8(1):92-9. PubMed PMID: 18173354. 